\title{
The International Human Resources Management Policies for the Development of the International Hotels' Organizational Learning Capability in Algeria
}

\author{
Dr. Khadra Dahou \\ Economics and Business Faculty, Tlemcen University, Algeria \\ E-mail: dahou.khadra@yahoo.fr \\ Dr. Ishaq Hacini \\ Economics and Business Faculty.Mascara University. Algeria \\ E-mail: ishaq_zida@yahoo.fr
}

Doi:10.5901/mjss.2015.v6n6s4p526

\section{Abstract}

Facing a globalized hyper-competitive economic environment and by necessity of becoming learning organizations, the importance of organizational learning (OL) has incredibly increased in multinational companies (MNCs) than those operating locally. The OL has become a distinctive competency that enables them invest successfully and compete overseas where they have to adjust their strategic choices to those regions in which they want to operate; especially in a newly emergent market of Algeria. In the other hand, managing a workforce of cultural diversity requires putting in place a clear strongly sophisticated policy; and having an international management cadre facilitate the mission of the MNCs in the different international settings. This research explores the extent to which the human resources management policies of the international hotels, installed in Algeria, affect the development of the organizational learning capability. The expatriates within those international hotels were asked to respond to the research survey. Results demonstrate a real positive significant effect of the international human resources management policies on the development of the organizational learning capability within international hotels installed in Algeria. In addition to the major role of the organizational learning capability in the strategic management and performance of the international hotels, applying the right international human resources strategies will yield sustainable international hotels competitive edge, mainly because of the sophistication of their services. They have to develop a cadre of top management with an international experience and capable to succeed in do business overseas and deal with and adapt to the different economic and cultural conditions of the host countries. This research may be first of kind in exploring the theme of organizational learning within MNCs, in an Arab developing country; specifically, the unique in studying the emergent promising Algerian sector of hospitality.

Keywords: Organizational learning capability, International human resources management policies, International Hotels, Algeria.

\section{Introduction}

A vital element in implementing global strategy is the international human resource management. When the factors of production (capital, technology, raw materials and information) become easily duplicated, "the caliber of the people will be the only source of competitive advantage" (Deresky, 2008)

Being a multinational company 'MNC' engages the organization to deal with a diverse geographically dispersed workforce. The MNC has to adopt special HRM practices, tailored to the host countries specifications: Business practices, legal issues, culture issues ... Flexible IHRM becomes indispensable global core processes for the MNC continuity; binding IHRM practices in a constant change and refinement processes.

For instant, facing a globalized hyper-competitive economic environment and by necessity of becoming learning organizations, the importance of organizational learning $(\mathrm{OL})$ has incredibly increased in MNCs than those operating locally. The OL has become a distinctive competency that enables them invest successfully and compete overseas where they have to adjust their strategic choices to those regions in which they want to operate, especially in a newly emergent market of Algeria.

The present research explores "to what extent the human resources management policies, applied internationally, affect the development of the organizational learning capability of the MNCs, especially in Algeria?" 


\section{Literature Review}

\subsection{The Organizational Learning Capability}

Confronting a hostel and turbulent business environment, the organizations focus their efforts on the development of a powerful process, that of the organizational learning. This learning represents the underpinning behind organizations' innovation, and thus sustainable competitive advantage (Dahou et al., 2012).

Diverse literature have taken into study and demonstrated the positive relationship between organizational learning and innovation (Camisón \& Villar-López, 2011; García-Morales et al., 2011; Jiménez-Jiménez \& Sanz-Valle, 2011; Aragón-Correaet al., 2007; Chen, Lin, \& Chang, 2009; Mavondo et al., 2005; Calantone et al., 2002; Hurley \& Hult, 1998).

Wang and Ellinger (2011) highlighted the importance of organizational learning for organization's strategic renewal. 268 senior R\&D project team members revealed the significant effect of organizational learning on either individual or organizational-level innovation performance.

From a study of 363 strategic alliances in Taiwanese companies, a number of drivers of organizational learning were cited, necessary for strategic alliances as learning oriented collaborative relationships: integration power of manager, external linkages, previous experience, repeated practice, codification of experience and ambiguity. Those learning mechanisms are influenced positively by learning intent and embedded learning, and lead to the development of dynamic competitive competencies, either competitive scanning competencies or quality management competencies (Chen et al., 2009).

Hurber, in 1991, proposed four basic constructs of OL, encompassing: knowledge acquisition, information distribution, information interpretation and organization memory.

Furthermore, Slater and Narver (1995 as cited in Jones, 2006a) added correspondingly that organizational learning "includes information acquisition, dissemination, shared interpretation and organizational memory".

The acquisition enables the organization generate new knowledge and information, either internally or externally, through interactions and communication processes and experiences of its members.

The obtained knowledge is then diffused to all the organization's members, and transformed from its tacit nature to more explicit form.

The third phase is the development of a shared interpretation of the diffused knowledge at the individual and organizational level, through formal networks and databases or informal interactions, making from it a common knowledge integrated in routines and enhanced through single or double-loop learning.

The four is the organizational memory, in which knowledge is embedded in the theory of use of the organization, transformed into action and stored and committed in declarative and procedural memory for prospective use (Dahou et al., 2012; García-Morales et al., 2011; Jiménez-Jiménez \& Sanz-Valle, 2011; Santos-Vijande et al., 2011; Jones, 2006a).

Furthermore, other researchers have chosen to point out the term "Organizational Learning Capability (OLC)". It stresses the key factors for organizational learning or the organizational propensity to learn. Goh \& Richards (1997, $p$. 577) defined it as the organizational and managerial characteristics or factors that facilitate the organizational learning process or allow an organization to learn (Jerez-Go'mez et al., 2005; Goh and Richards, 1997; Hult and Ferrell, 1997; Dibella et al., 1996).

In 2007, Chiva, Alegre \& Lapiedra proposed a model of organizational learning capability as a measurement scale encompassing the major facilitators of organizational learning based on literature of the different scales of organizational learning. In 2009a,b, Chiva \& Alegre identified the five precedent dimensions or facilitating factors as they called them for organizational learning capability, taking them into study with different subject such as entrepreneurial orientation, innovation, job satisfaction and firm performance.

When analyzing such definition used in tremendous research, the researchers found that searching for the characteristics or dimensions that facilitate OL are in fact the same interests of the LO literature. So critically thought, the term capability in this research is taken to mean "capacity" or "ability" of organizations to develop and accomplish the OL process and more importantly promote such process into a distinctive competency; and both OL literature and LO literature were considered when measuring $\mathrm{OL}$ in this research, marrying both the factors of OLC scale and dimensions of LO.

\subsection{International Human Resources Management Policies}

Being a MNC engages the organization to deal with a diverse geographically dispersed workforce. The MNC has to adopt special HRM practices, tailored to the host countries specifications: Business practices, legal issues, culture issues ... 
Flexible IHRM becomes indispensable global core processes for the MNC continuity; binding IHRM practices in a constant change and refinement processes.

"Global firms often struggle to replicate practices among their culturally and geographically dispersed subsidiaries. Part of the reason for this is that certain practices, including human resource management (HRM) practices, are complex and context specific" (Morris et al., 2009, p. 293).

Some researchers say that MNCs have to replicate and imitate the best HRM practices in the host countries as an incentive for and critical to the realization of goals and thus the achievement of the MNC competitive advantage.

Lado and Wilson (1994, p. 699) suggested those HRM practices which "can contribute to sustained competitive advantage through facilitating the development of competencies that are firm specific, produce complex social relationships, ... and generate organizational knowledge", which means in total "Organizational Learning"

IHRMP encompass in its true term "learning mechanisms": planning, stuffing, training and development, appraising and performance management of either expatriates or local nationals, compensation of expatriate managers along with attention put on labor relations issues in every subsidiary location.

Those learning mechanisms are requirements for the MNCs for their performance in the host countries' markets, via promoting their adaptability and innovation, especially in the presence of real knowledge transfer and sharing across the MNCs units. The result is a very interactive "transnational learning that increases the MNCs worldwide competitiveness and thus their very long continuity, in much diversified business contexts.

Acting globally, the MNCs are obliged to align their HR strategies to their global strategies. They have to adopt global stuffing, development and compensation strategies in attracting, hiring and retaining and developing either parentcountry nationals (expatriates), host-country nationals (locals) or third-country nationals.

Supplementary, recruiting host-country nationals and third-country nationals will get high investment in term of training from host nationals either on technical areas, in product and service systems, business systems, conduct policies or corporate culture.

There exists a number of stuffing philosophies for international operations: (Deresky, 2008)

$\stackrel{m}{\rightarrow}$ The MNC that use an ethnocentric staffing approach fills key managerial positions with people from headquarters - that is, parent-country nationals (PCNs).

$\stackrel{\leftrightarrow}{\rightarrow}$ In a polycentric staffing approach, local managers - host-country managers ( $\mathrm{HCNs})$ - are hired to fill key positions in their own country.

$\rightarrow$ In the global staffing approach, the best managers are recruited from within or outside of the company, regardless of nationality.

$\stackrel{4}{\rightarrow}$ In a regiocentric staffing approach, recruiting is done on a regional basis - say within Africa for a position in Algeria.

Before sending expatriates overseas, the MNC has to take into consideration a number of factors that affect directly the success of their assignments: personality and psychological issues like emotional maturity, adaptive and flexible thinking; prior experiences overseas, languages, openness to sundry cultures, family support and issues, and most importantly their ability to learn new customs and traditions and more specifically styles of management and technological capabilities in the host country (Geigle \& Malhotra, 2009).

In 2002, a Canadian qualitative research was conducted, investigating the best HRM practices in expatriation management in four Canadian MNCs. It pointed out the significance of appropriate IHRM practices. Job specification is one of those practices, specifying the set of cross-cultural competencies going beyond specific technical requirements. The recruitment process is another practice where a realistic job preview is prepared, facilitating this process by giving information concerning career development, political conditions, quality of living conditions, difficulty of spousal adjustment -which had reportedly huge impact on expatriate success- and finally length of assignment. The IHRM practices includes also the selection process that should entails interviews, tests especially the most recommended big five personality test, and taking into account the biographical data of candidates.

Yet, those practices would have consequences on training that equips expatriates for assignment, performance appraisal, human resource development to retain high performers and providing convenient post-return jobs, and human resource planning. The findings indicated that the MNCs under study neglected the cross-cultural competencies (attitudinal, interpersonal and general living). They excluded spouses from the realistic job preview, in addition to the omitting of the bibliographical data during the selection process. The findings exhibited the absence of explicit references to cross-cultural challenges in performance appraisals and rater training (O'Sullivan et al., 2002).

For international assignments, Stone (1991) proposed a number of personal characteristics taken as criteria for expatriates' selection: ability to adapt; technical competence; spouse and family adaptability; human relations skill; desire to serve overseas; previous overseas experience; understanding of host country culture; academic qualifications; 
knowledge of language of the host country; and understanding of home country culture.

Another study of Salleh (2012) mentioned the expatriates' performance determinants that MNCs should take into consideration when managing international assignments. Table.1 summed most determinants of expatriates' performance cited in literature between the 1980s and 2000s.

Others research has determined (Caligiuri, 2000; Viswesvaran and Ones, 1999; Behling, 1998; Hogan et al., 1996.a, 1996.b; Buss, 1991), based on the personality model of the Big Five, the five key characteristics of expatriate's selection: extraversion, agreeableness, conscientiousness, emotional stability and openness and intellect.

Table.1. Determinants of expatriates' performance

\begin{tabular}{|c|c|c|c|c|}
\hline Year & Most Cited & Expatriate & Family & Organisation \\
\hline \multirow[t]{3}{*}{$1980 \mathrm{~s}$} & (Tung, 1987) & $\begin{array}{l}\text { Adaptability level, technical } \\
\text { competency, maturity level, } \\
\text { language capability, } \\
\text { experience, motivational } \\
\text { level }\end{array}$ & $\begin{array}{l}\text { Family } \\
\text { situation }\end{array}$ & $\begin{array}{l}\text { Training. } \\
\text { performance, } \\
\text { support, } \\
\text { preparation, and } \\
\text { planning system }\end{array}$ \\
\hline & $\begin{array}{l}\text { (Black 1988; Black \& } \\
\text { Stephens 1989) }\end{array}$ & Effectiveness of roles played & $\begin{array}{l}\text { Spousal } \\
\text { influence }\end{array}$ & \\
\hline & $\begin{array}{l}\text { (Mendenhall, Dunbar } \\
\& \text { Oddou 1987) }\end{array}$ & $\begin{array}{l}\text { Self-oriented, perception } \\
\text { dimension }\end{array}$ & & $\begin{array}{l}\text { Superiors, } \\
\text { subordinates' } \\
\text { influence }\end{array}$ \\
\hline \multirow[t]{6}{*}{$1990 s$} & (Gertsen 1990) & Intercultural competency & & \\
\hline & $\begin{array}{l}\text { (Black \& Gregersen } \\
\text { 1991) }\end{array}$ & & $\begin{array}{l}\text { Spousal } \\
\text { adjustment }\end{array}$ & \\
\hline & $\begin{array}{l}\text { (Arthur \& Bennett } \\
\text { 1995) }\end{array}$ & Inter-cultural adjustment & & \\
\hline & $\begin{array}{l}\text { (Harrison, Chadwick \& } \\
\text { Scales 1996) }\end{array}$ & Cross-cultural adjustment & $\begin{array}{l}\text { Family } \\
\text { situation }\end{array}$ & \\
\hline & $\begin{array}{l}\text { (Caligiuri, Hyland, } \\
\text { Joshi, Bross 1998) }\end{array}$ & Adjustment capability & $\begin{array}{l}\text { Adjustment } \\
\text { capability }\end{array}$ & \\
\hline & $\begin{array}{l}\text { (Shaffer, Harrison \& } \\
\text { Gilley 1999) }\end{array}$ & $\begin{array}{l}\text { Adjustment level and work } \\
\text { related factor }\end{array}$ & & \\
\hline \multirow[t]{5}{*}{$2000 s$} & (Caligiuri 2000) & Personality characteristics & & $\begin{array}{l}\text { Cross-cultural } \\
\text { training }\end{array}$ \\
\hline & (Kraimer \& A 2001) & $\begin{array}{l}\text { Perceived support of } \\
\text { organisation }\end{array}$ & & $\begin{array}{l}\text { Organisation } \\
\text { support }\end{array}$ \\
\hline & $\begin{array}{l}\text { (Takeuchi, Yun \& } \\
\text { Tesluk 2002) }\end{array}$ & Cultural adjustment & $\begin{array}{l}\text { Spousal } \\
\text { adjustment }\end{array}$ & \\
\hline & $\begin{array}{l}\text { (Hechanova, Beehr \& } \\
\text { Christiansen 2003) }\end{array}$ & Adjustment capability & $\begin{array}{l}\text { Family } \\
\text { support }\end{array}$ & $\begin{array}{l}\text { Interaction with } \\
\text { host nationalities }\end{array}$ \\
\hline & $\begin{array}{l}\text { (Shaffer, Harrison, } \\
\text { Gregersen, Black, } \\
\text { Ferzandi 2006) }\end{array}$ & $\begin{array}{l}\text { Personality and behavioural } \\
\text { competency }\end{array}$ & & \\
\hline
\end{tabular}

Source: Salleh, 2012

Others research has determined (Caligiuri, 2000; Viswesvaran and Ones, 1999; Behling, 1998; Hogan et al., 1996.a, 1996.b; Buss, 1991), based on the personality model of the Big Five, the five key characteristics of expatriate's selection: extraversion, agreeableness, conscientiousness, emotional stability and openness and intellect.

Indicating the importance of expatriates training as a key for international assignments success, and from 400 expatriates in China and Taiwan, Lee \& Croker (2006) found negative impact of the expatriate's characteristics, specifically competence and adaptability to work abroad, on its needs of training. In addition, task assignment complexity, capability of the host country managers and cross-cultural differences have an impact also on expatriates needs for training. The researchers concluded also that the fit between the expatriate's learning style and instructor teaching mode moderates the need for training and the training effectiveness.

Generally, expatriates need many kinds of training, imposed by the requisites of cross-cultural contexts, in an attempt to reduce the expatriates and their families' culture shock and their expatriation failure (Kangas, 2012; Chitakornkijsil):

- Cultural Savvy: by developing a working knowledge of the foreign cultural variables affecting management decisions

- Language training: an inability to speak the local language and a poor or too literal translation are often causes for mistrust of local employees. Getting language training would enhance the task performance and cultural adjustment, improve the negotiation ability, and access to information and effectiveness. 
- Pre-departure training: getting an introduction to the host country.

- Sensitivity training: or cultural empathy, means that expatriates should develop an awareness and an honest caring about the local employees' culture.

- Repatriation training: to prepare the expatriate and his family to the reverse culture shock.

From 331 Taiwanese expatriates in Shanghai, Lee (2006) found that expatriates' job satisfaction impacted their cross-cultural adjustment in Shanghai. The researcher compared his results with those of Lee (2002), who found that when Taiwanese expatriates felt satisfied in their jobs in the banking sector, this affects their cross-cultural adjustment in USA. The researcher recommended taking his findings into account when managing the MNC expatriation processes.

Later, in 2007, a study revealed that a holistic approach should be used by multinational hotel companies - where expatriation experiences high rate of failure- when selecting and training expatriates, and most importantly organizational support; entailing factors that could enhance the expatriates' success odds like expatriate's family status, emotional intelligence, dietary and exercise habits and expatriates learning orientation. Continuous support would certainly lessen the effect of the culture shock in the host country. Further, developing an enticing compensation system might be a source of motivation for accepting the assignment, as a reward for sacrificing part of their lives abroad (Avril \& Magnini, 2007).

Furthermore, literature reported high failure rate of traditional assignment or long-term assignment, in contrast to the non-traditional assignments' forms or short-term assignments. Table.2 exhibits the new forms of international assignments.

Table 2. Forms of Non-Traditional Assignments

\begin{tabular}{|c|c|}
\hline $\begin{array}{l}\text { Form of international } \\
\text { assignments }\end{array}$ & Length of Assignments \\
\hline Short-term & $\begin{array}{l}\text { A short-term assignment involves sending a manager to a foreign } \\
\text { country for a duration of between } 1 \text { and } 12 \text { months (Tahvanainen, } \\
\text { Welch \& Worm, 2005) }\end{array}$ \\
\hline Rotational & $\begin{array}{l}\text { Staff commute from the parent country to a workplace in another } \\
\text { country for a short period followed by a break in the home country: } \\
\text { for example, this type of arrangement is very common in the oil rigs } \\
\text { (Welch \& Worm, 2006). }\end{array}$ \\
\hline International commuter & $\begin{array}{l}\text { An employee who commutes from the home base to a post in another } \\
\text { country, generally on a weekly or bi-weekly basis. This does not } \\
\text { involve family relocation (Scullion \& Collings, 2006a) }\end{array}$ \\
\hline $\begin{array}{l}\text { International business } \\
\text { traveller (IBT) }\end{array}$ & $\begin{array}{l}\text { A staff member who makes short visits to the foreign market, unit, } \\
\text { project, and the like (Marschan, Welch \& Welch, 1996) }\end{array}$ \\
\hline Frequent flyer & $\begin{array}{l}\text { An employee who undertakes frequent international business trips } \\
\text { but does not relocate (Harris, 2002) }\end{array}$ \\
\hline Contractual assignment & $\begin{array}{l}\text { A staff member with specific skills which are essential for completing } \\
\text { international projects is assigned for a limited period of } 6-12 \text { months } \\
\text { (Scullion, \& Collings, 2006a) }\end{array}$ \\
\hline Boundary spanner & $\begin{array}{l}\text { An individual whose job role places him or her in the position to } \\
\text { engage in significant transactions with external agents (Yongsuk, } \\
\text { 2008) }\end{array}$ \\
\hline
\end{tabular}

Source: Salleh, 2012.

Additionally, Friedman (2007) argued that "The ability to implement best practices in a way that is acceptable in local situations and create alignment across different cultural and business environments is, in part, the domain of HRM".

In other hand, the compensation and benefits strategy represents a crucial link between the MNC strategy and its implementation. It must exist strong fit between the compensation strategy and the MNC whole goals.

Jayasekara and Takahashi (2012) investigated the effect of the international human resource management practices on 277 assignees in small and medium-sized enterprises (SMEs) in Sri Lanka. The findings indicated that recruitment, training and compensation have significant positive effect in improving the behavioral performance of the short term assignees while preparation, selection and performance evaluation hadn't an effect.

In 2013, Kavukcuoglu reported the results of an international survey about the most challenges facing the management of human resources in 164 organizations in 7 continents. The major challenge is stated as «retention of key talent/high performers/high potentials»; by $45 \%$ of the overall participants, followed by HR measurement and transforming into strategic business partner role and performance management respectively; in addition to developing future leaders 
and succession planning consecutively.

From this point researchers propose the following hypothesis:

Ho.1: IHRMP have no statistical significant influence on developing $\mathrm{OL}$ in international settings.

\section{Operational Definitions}

For the IHRMP, the following definition is given: "IHRMP encompass "learning mechanisms": planning, stuffing, training and development as the strategic cornerstones of the organizational development and the organizational learning, effective equitable appraising and performance management of either expatriates or local nationals, providing attractive equitable compensation and benefits system of expatriate managers along with attention put on labor relations issues in every subsidiary location, dealing with diversity in the workforce; building appraisal systems, be socially responsible, in addition to other human resource management practices like motivation, teamwork, empowerment..." (Dahou, 2015).

The definition sources are: Doz and Prahalad, 1991; Schuler et al., 1991; Stone, 1991; Lado and Wilson, 1994; Shuler and Florkowski, 1994; O'Sullivan et al., 2002; Engelhard \& Na"gele, 2003; Lee \& Croker, 2006; Stiles et al., 2006; Avril \& Magnini, 2007; Aswegen, 2008; Deresky, 2008; Morris et al., 2009; Geigle \& Malhotra, 2009; Nicely, 2009; Takeda \& Helms, 2010; Brewster et al., 2011; Jayasekara and Takahashi, 2012; Kangas, 2012; Salleh, 2012; Kavukcuoglu, 2013.

For OLC, the following definition is provided as follow: "The adaptive process through which MNCs respond to cross-cultural environmental changes by re-ajusting their goals, attention rules, and service rules. MNCs change their goals, shift their attention, and revise their procedures for search as a function of their experience. This process encompass information acquisition, dissemination, shared interpretation and organizational memory, experimentation, risk taking, interaction with the external environment, dialogue and participative decision making." (Dahou, 2015)

The sources of this definition are: Watkins \& Marsick's LODQ, 1993; Dibella et al., 1996 ; Hult and Ferrell, 1997; Goh \& Richards, 1997; Schwandt \& Marquardt, 2000; Gençturk \& Ozsomer, 2003; Jerez-Go'mez et al., 2005; Jones, 2006a; Real, Leal \& Rolda, 2006; Chiva, Alegre \& Lapiedra, 2007; Myloni et al., 2007; García-Morales et al., 2011; Jiménez-Jiménez \& Sanz-Valle, 2011; Mauchet, 2011; Santos-Vijande et al., 2011; Dahou et al., 2012; Fraj et al., 2015.

\section{Methodology}

To achieve the overall aim, and objectives of this research, researcher adopted a deductive approach with a descriptive purpose. Also, it is a non-causal correlational study. This non-contrived field study research has hypotheses testing purpose, testing the variance in and dependency of the development and sustainability of organizational learning capability on the IHRMP.

Researchers use non-probability purposive judgment sampling. For this research, expatriates within the international hotels and those who manage them in distance represent the population of interest. From 70 targeted participants, the researcher has gotten a number of 47 questionnaires.

Using a triangulation methodology, Research data was collected from primary resources using questionnaire and secondary resources. The questionnaire consists of two sections. The first section covered some of the individuals' demographic related information concerning participants' gender, age, academic qualifications, work experience, expatriation duration and business area. The second section measured the dependent variables: Organizational Learning Capability with 25 items, International Human Resource Management Policies measured by 21 items. Each item was surveyed using a five point Likert scale with scales ranging from "1- strongly disagree" to "5- strongly agree". Data is analyzed using SPSS version 22.

\section{Results and Discussion}

\subsection{Sample Descriptive}

From results of descriptive statistics of the research sample, (87.2\%) of the sample are males, meaning that sample has a masculinity characteristic. Most respondents have an age between 30 and 35 years with a percentage of (32\%) of the sample. Also, as it appears, the academic qualification of MBA/Master prevails between respondents (61.7\%). Those expatriates have a working experience between 3 and 8 years with response rate of $29.8 \%$, followed by $25.5 \%$ of the respondents with an experience of 15 to 25 years. The average of the expatriates assignment duration range between 1 3 year and less than 1 years (46\% and 38\% consecutively). Finally, most expatriates are generally senior executives (38\%). 
Those scores are quit logical regarding the empirical evidences in literature. For example, the academic qualification of expatriates is referred to the development pursued within the hotels specific Business Schools like that of Hilton or Carlson Rezidor, which offers undergraduate and an MBA/ Master for its employees. Regarding the expatriation duration, the research has proven the failure of the longue assignment and a range of assignment alternatives is present now for expatriates, like those already mentioned in table.2. originated from Salleh research (2012).

For experience, the researchers are convinced that entering a new emergent market in a developing country necessitates well experienced leaders with specific global characteristics and high accumulated know-how. But this does not stop new bright persons to get the change of developing their global career.

\subsection{Reliability \& Validity}

For this research, content validity is considered because of the generalization of the model's variables of OLC and IHRMP: "The more the scale items represent the domain or universe of the concept being measured, the greater the content validity" (Sekaran, 2006: p.206).

For reliability, Researchers used Cronbach' alpha as a reliability measure for survey items, exhibiting the following in Table 3:

Table 3. Variables' Reliability

\begin{tabular}{|lcccc|}
\hline Variable & Dimensions & No. of Cases & No. of liems & Alpha \\
\hline IHRMP & 47 & 20 & .841 \\
\hline OLC & 47 & 26 & .758 \\
\hline
\end{tabular}

\subsection{Hypothesis Testing}

Before proceeding the influence of the research independent variable on the dependent variable using a regression analysis, it is logically to see if there is any relationship between those variables. A Pearson Correlation Matrix can be of useful explanation of this relationship.

Table 4. Pearson Correlation Coefficient between Variables

\begin{tabular}{|c|c|}
\hline Variable & Coefficient \\
\hline IHRMP & $.486^{*}$ \\
\hline
\end{tabular}

*. Significant at the 0.05 level.

As it appears in the Table.4, the IHRMP is significantly positively correlated to the OLC variable, at a significance level of $5 \%$.

In order to test the research hypothesis, a simple linear regression test is conducted

Table 5. Simple Linear Regression Results

\begin{tabular}{|c|c|c|c|}
\hline \multicolumn{2}{|c|}{ R-squared: .236 } & \multicolumn{2}{|c|}{$\begin{array}{l}\text { F-statistic: } 10.98 \\
\text { Probability : } 0.03\end{array}$} \\
\hline Variable & Coefficient & T-Statistic & Probability \\
\hline IHRMP & .231 & 3.23 & $.003^{*}$ \\
\hline
\end{tabular}

The results indicate that $\mathrm{R}^{2}=23.6 \%$, significant at $5 \%$. This means that $23.6 \%$ of the variance in the dependent variable "OLC" is explained by the independent variable of IHRMP. These results make $\mathrm{H} 1$ accepted

\subsection{Discussion}

In this research, International Human Resource Management policies affect the development of organizational learning capability within international hotels in Algeria. Developing an international human resources management is visibly one of the major areas of interest in international management (Shuler and Florkowski, 1994; Doz and Prahalad, 1991; 
Schuler et al., 1991), entailing real complexities when managing diversity of people across borders, and within competitive challenges. Broadly, IHRM enables the MNCs to success in their international businesses (Shuler and Florkowski, 1994, Brewster et al., 2011).

Through effective IHRMP, MNCs sustain their competitivity, their efficiency, local responsiveness, quick flexibility and adaptability, and most importantly, capability to transfer learning across globally dispersed units (Takeda \& Helms, 2010).

Accordingly, in a really globalized working environment, full of challenges, the international human resources management policies change always the rules of games. Those policies become more and more strategic for MNCs. This is why the variable of international human resources management is found to have an influence on the development of the organizational learning strategic capability.

It is the human aspect that makes the difference. Thus, pursuing the right effective recruitment and selection tactics from the national, host or third countries, dealing with diversity in the workforce; offering the right training and development systems to employees as the strategic cornerstones of the organizational development and the organizational learning; building effective equitable appraisal systems, providing attractive equitable compensation and benefits system; be socially responsible, in addition to other human resource management practices like motivation, teamwork, empowerment... build up MNCs' successful IHRM.

In 2009 , Nicely advocated hotels, willing to promote their managers' work-related learning, to hire persons with a wide experience, as the greater the amount of experience accumulated from different entities, the greater the knowledgebase they apply. Nicely added that hotels should embrace and sustained a learning culture that supports managers' regular engagement in internal or external hospitality training and other job experience.

In 2008, Fenton-O'Creevy et al., investigated the impact of national contexts of Europe and Australia on the US subsidiaries autonomy. The results of 411 surveys - were 4\% in Denmark and Norway, 8\% in Germany, 11\% in UK, 22\% in Ireland and $23 \%$ in Australia - showed that the subsidiaries autonomy in HRM is highly determined by strategic context. The results argued that subsidiaries which serve domestic markets have stronger local HRM autonomy than those acting internationally. The institutional location and possible confrontations with labor unions impact also the subsidiaries HRM autonomy. The searchers indicated that US MNEs centralized control of HRM where subsidiaries confronted global markets and low union density.

Stiles et al., (2006), in an attempt to identify the best practices in global human resource management, reported that expanding internationally needs attention on consistency and flexibility of the use of global standards and balancing this use with local context sensitivity. Strict recruitment and selection procedures; training and development, developmental appraisal and performance-linked pay, flexible job design, minimized organizational hierarchies; team working; empowerment and two-way communications were common features in HR management across companies. The results leaded also to an application of a local view using local knowledge.

Stiles et al., implied that any global human resource practice should be first aligned with the business need at corporate and local levels, and then integrated it with other HR practices, and with the human, social, organizational elements of the organization upon which its effectiveness is dependent. The researchers underlined the relationship IHRMP and leadership. They highlighted that via the role, the strength and quality of leadership, the IHRMP may add value. They added that leadership ensures congruence between diverse elements of the organization, its environment, strategy and structures, and tactically reconciling the inevitable but unsuspected tensions inherent within large complex arising organizations.

Carlson Rezidor offers special training and development to its employees, in which each management level has a specific program:

- For employees (New Hire Orientation Program, , Living Responsible Business, On Job Skills Training, The Learning Network (online)),

- For supervisor (On Job Skills Master Trainer, Leading Responsible Business, Supervisory Training and Resource Program (STAR), Management Development Program, Business School @Carlson Rezidor),

- For heads of departments (Business School @Carlson Rezidor, Mentee Program, Management/Leadership program (launched in 2014)),

- For general managers (Business School @Carlson Rezidor, Pro Active Leadership, Mentor program, Performance Management Process \& Appraisal Skills, Competency Based Interview Technique),

- Finally for top management (Pro-active Leadership, Performance Management Process \& Appraisal Skills, Competency Based Interview Technique, Individualized learning) ${ }^{1}$.

\footnotetext{
${ }^{1} \mathrm{http}: / / w w w . r e z i d o r . c o m /$ phoenix.zhtml?c=205430\&p=careersmanamentdev
} 
This program exhibits a high potential for career development within Rezidor, to be promoted for example into a head of department within two years, designed for the exploration and exploitation of potential inspirational leaders.

For Accor Hotel, the learning strategy is in fact embedded in its corporate strategy and a cornerstone of its training and development programs. In 2012, Sophie Flak, Executive Vice President Sustainable Development and Académie Accor explained2:

"Today, more than ever, identifying, developing and retaining talented people is a crucial guarantee for Accor's strategy of conquest. With 40,000 new rooms every year, our mission is to train our employees on the ground, where they work. The Académie Accor therefore offers an increasingly varied mix of training approaches brought together under the name "blended learning". We train all our employees, whether they work in owned, managed or franchised hotels, face-to-face or remotely, via e-learning modules or virtual classrooms".

Regarding compensation and benefits, Accor hotel provides an enticing compensation package, based on skills and performance, equity and non discrimination.

Since 2000, Accor carries out (in almost 30 countries whose law permits it) a shareholding system "Accor in Actions", a motivating formula which regularly enables employees to purchase Accor shares on preferential terms and conditions. At the end of 2010, this system has enabled 19242 employees to become Group shareholders, owning $1.08 \%$ of the capital share.

Concerning Expatriation, Accor has a motivating international mobility policy in the different professions. Withal, diversity represents a key for the hotel's performance: "We learn to respect the specifics of each culture. Day to day, the pluralism of our team is very rewarding. This diversity is also positive for our customers. Understanding our employees' cultures helps us to better understand our international clientele. We can adapt our attitudes and quality of service". The hotel employees from around the world cultivate their differences around a common culture. ${ }^{3}$

\section{Conclusion and Recommendations}

In the long run, the only sustainable source of competitive edge is your organization's ability to learn faster than its competitors (Senge, 2006).

Nowadays, Organizational Learning Capability is seen as being "a distinctive competency", the fulcrum of the strategic management of MNCs and their growth and survival. Trim \& Lee (2007) developed a conceptual model outlining how organizational learning underpins the strategic management process:

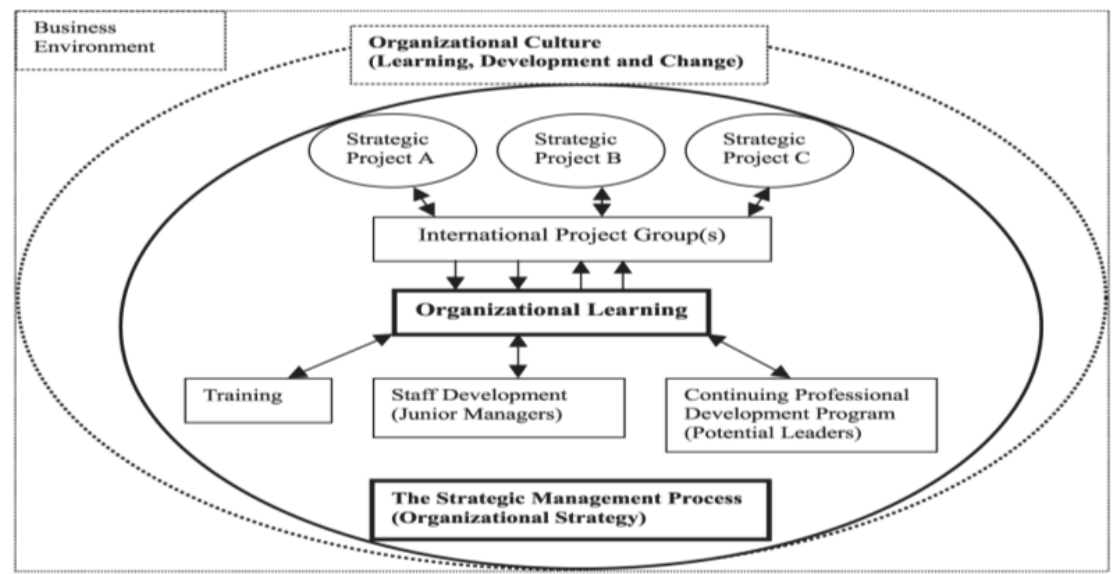

Figure.1. A conceptual model outlining how organizational learning underpins the strategic management process Source: Trim \& Lee (2007)

\footnotetext{
2 http://www.hospitalitynet.org/news/4056725.html

${ }^{3}$ http://www.accor.com/
} 
The research investigates one of the success factors assisting in developing organizational learning capability in international settings in Algeria, that of international human resources management policies.

Research findings revealed that IHRMP has an influence on the building of the organizational learning capability, explaining $23.6 \%$ of the variance in it.

International Human Resource Management policies are found to have a lowest but significant impact on building Organizational Learning Capability. Developing an international human resource management is one of the major areas of interest and critical issues in international management, entailing real complexities of diversity, within unpredicted competitive challenges.

Through effective IHRMP, MNCs sustain their competitivity, their efficiency, local responsiveness, quick flexibility and adaptability, and most importantly, capability to transfer learning across globally dispersed units.

Moreover, international managers know very well that "people are the most important asset" of the organizations. They are the source of distinctiveness. So, dealing with a diverse workforce from the world wild, from different cultural backgrounds is the real challenge.

International managers have to pursue the right effective stuffing, the right training and development systems, equitable appraisal systems; attractive equitable compensation and benefits system; be socially responsible.

Additionally, Developing Organizational Learning Capability imposes some organizational transformations, especially a teamwork organization on an international level which becomes "a must" nowadays. Managers have to develop a cadre of top management with an international experience and capable to succeed in do business overseas and deal with and adapt to the different economic and cultural conditions of the host countries.

This research may be first of kind in exploring the theme of organizational learning within MNCs, in an Arab developing country; specifically, the unique in studying the emergent promising Algerian sector of hospitality.

As it appears, the model variable within this context is found to explain approximately $24 \%$ of Organizational Learning Capability, which means that $76 \%$ of the variance is referred to other variables. So, an exploration of these variables would also provide new information.

\section{References}

Aragon-Correa, J., A., García-Morales, V., J., \& Cordon-Pozo, E. (2007). Leadership and organizational learning's role on innovation and performance: Lessons from Spain. Industrial Marketing Management, 36, 349 - 359.

Argyris, C., \& Schon, D. (1978). Organizational learning: a theory of action perspective. Addison-Wesley Publishing Company.

Aswegwn, M. V. (2008). The establishment of an adjustment model for expatriates. Unpublished Doctoral Dissertation. University of Pretoria.

Avril, A. B., \& Magnini, V. P. (2007). A holistic approach to expatriate success. International Journal of Contemporary Hospitality Management, 19 (1), 53-64.

Behling, O. (1998). Employee selection: Will intelligence and conscientiousness do the job?. Academy of Management Executive, 12, $77-86$.

Brewster, C., Sparrow, P., Vernon, G., \& Houldsworth, E. (2011). International Human Resource Management. $3^{\text {rd }}$ Edition. Chartered Institute of Personnel and Development, London, UK

Caligiuri, P. M. (2000). The big five personality characteristics as predictors of expatriate's desire to terminate the assignment and supervisor-rated performance. Personnel Psychology, 53 (1), 67-88.

Camison, C. \& Villar Lopez, A. (2011). An examination of the relationship between manufacturing flexibility and firm performance: The mediating role of innovation. International Journal of Operations \& Production Management, 30 (8), 853-878.

Chen, H-H., Lee, P-Y., \& Lay, T-J. (2009). Drivers of dynamic learning and dynamic competitive capabilities in international strategic alliances. Journal of Business Research, 62, 1289-1295.

Chen, Y-S., Lin, M-J., \& Chang, C-H. (2009), The positive effects of relationship learning and absorptive capacity on innovation performance and competitive advantage in industrial markets. Industrial Marketing Management, 38, 152-158.

Chitakornkijsil . The internationalization of human resource management in the host nation context \& strategic approach of IHRM. The International Journal of Organizational Innovation.

Chiva, R., Alegre, J., \& Lapiedra, R. (2007). Measuring organizational learning capability among the workforce. International Journal Of Manpower, 28 (3/4), 224-242.

Chiva, R. and Alegre, J. 2009 Organizational learning capability and job satisfaction: An empirical assessment in the ceramic tile industry. British Journal of Management, 20 (3), 323- 340.

Dahou. K. (2010). An empirical investigation of factors determining a learning organization: The context of Sonatrach. Published MBA Dissertation, Mutah Univesity. Jordan.

Dahou, K., Hacini, I., \& Bendiabdellah, A. (2012). Sustaining competitive advantage via organization's innovation: The role of organizational learning and market orientation. Paper Presented at the national colloquium of Globelics and ISGP: "Innovation for competitiveness and development: What prospect for a successful take off in Algeria". Algiers - Algeria. April 16/19th, 2012. 
Dahou, K. (2015). The organizational Learning capability as a distinctive competency for international companies' strategy implementation in Algeria. Unpublished PhD Dissertation. Tlemcen University. Algeria.

Deresky, H. (2008). International management: A cross managing borders and cultures. USA: Pearson, $6^{\text {th }} \mathrm{Ed}$.

DiBella, A., \& Nevis, E. (1998). How organizations learn. San Francisco, CA: Jossey Bass Inc.

Doz, Y. and Prahalad, C. (1991). Managing DMNCs: a search for a new paradigm. Strategic Management Journal, 12, 145-63.

Engelhard, J. \& Na"gele, J. (2003). Organizational learning in subsidiaries of multinational companies in Russia. Journal of World Business, 38, 262-277.

Fenton-O'Creevy, M., Gooderham, P., \& Nordhaug, O. (2008). Human resource management in US subsidiaries in Europe and Australia: centralisation or autonomy?. Journal of International Business Studies, 39 (1), 151-166.

Fraj, E., Matute, J., \& Melero, I. (2015). Environmental strategies and organizational competitiveness in the hotel industry: The role of learning and innovation as determinants of environmental success. Tourism Management, 46, 30-42.

Garcia-Morales, V., J., Verbu-Jover, A., J., \& Llorens, F., J. (2009). The influence of CEO perceptions on the level of organizational learning. International Journal of Manpower, 30 (6), 567-590, 0143-7720.

García-Morales, V., J., Jiménez-Barrionuevo, M., M. \& Gutiérrez-Gutiérrez, L. (2011). Transformational leadership influence on organizational performance through organizational learning and innovation. Journal of Business Research - 07187.

Geigle, M., \& Malhotra, N. K. (2009). The expatriate experience: A case study of a pharmaceutical company in the European Union. International Business \& Economics Research Journal, 8(4), 59-66.

Gençturk, E., \& Ozsomer, A. (2003). A resource-based model of market learning in the subsidiary: the capabilities of exploration and exploitation. Journal of International Marketing, 11, 3. 1-29.

Goh, S. and Richards, G. (1997). Benchmarking the learning capability of organizations. European Management Journal, 15 (5), $575-83$.

Hogan, J., \& Hogan, R. (1996). Motives, values, performance manual. Tulsa, OK: Hogan Assessment Systems.

Hogan, J., \& Roberts, B. W. (1996). Issues and non-issues in the fidelity- bandwidth trade-off. Journal of Organizational Behavior, 17, $627-637$.

Hurley, R., \& Hult, T., M. (1998). Innovation, market orientation, and organizational learning: An integration and empirical examination. Journal of Marketing, 62, 42-54.

Jayasekara, P., \& Takahashi, Y. (2013). International Human Resource Management Practices and Their O utcomes in SMEs: A case of International Assignees in Sri Lanka. International Proceedings of Economics Development \& Research, 55, 125.

Jerez-Gomez, P., Céspedes-Lorente, J., \& Valle-Cabrera, R. (2005). Organizational learning capability: a proposal of measurement. Journal of Business Research, 58, 715- 725.

Jiménez-Jimenez, D., Sanz-Valle, R. \& Hernandez-Espallardo, M. (2008). Fostering innovation :The role of market orientation and organizational learning. European Journal of Innovation Management, 11 (3), 389-412.

Jones, W. D. (2006a). The impact of entrepreneurial strategies and organizational learning on firm performance in transitional environments: an empirical study in China and Vietnam. Unpublished Doctoral Dissertation. University of Hawai'i.

Kangas, L. (2012). Expatriation and cross cultural training. Unpublished thesis. Vaasan ammattikorkeakoulu, University of Applied Sciences.

Lado, A. and Wilson, M. (1994). Human resource systems and sustained competitive advantage: a competency-based perspective. Academy of Management Review, 19, 699-727.

Lee, H-W. (2002). A study of Taiwanese banking expatriates in the united states. Published Dissertation. University of Idaho.

Lee, C-Y. (2006). Job satisfaction affecting cross-cultural adjustment of Taiwanese expatriates. Journal of Business Systems, Governance and Ethics. Victoria University.

Lee, L-Y., \& Crocker, R. (2006). A contingency model to promote the effectiveness of expatriate training. Industrial Management \& Data Systems, 106 (8), 1187-1205.

Mauchet, M. (2011). Managers' Perceptions of Organizational Learning and Organizational Innovativeness in a Global Healthcare Organization. Unpublished Doctoral Dissertation. George Washington University.

Mavondo, F., T., Chimhanzi, J., \& Stewart, J. (2005). Learning orientation and market orientation. Relationship with innovation, human resource practices and performance. European Journal of Marketing, 39, 1235-1263.

Morris, S. S., Wright, P. M., Trevor, J., Stiles, P., Stahl, G. K., Snell, S., \& Farndale, E. (2009). Global challenges to replicating HR: The role of people, processes, and systems. Human Resource Management, 48 (6), 973- 995.

Nicely, A. (2009). Enhancing hotel learning: the impact of managers' engagement learning activities on their self-reported work-related learning levels. Unpublished Doctoral Dissertation. Oklahoma State University.

O'Sullivan, S. L., Appelbaum, S. H., \& Abbikhzer. C. Expatriate management "best practices" in Cnadian MNCs: Multiple case study. Career Development International, 7 (2), 415-429.

Real, J., C., Leal, A., \& Roldan, J., L. (2006). Information technology as a determinant of organizational learning and technological distinctive competencies. Industrial Marketing Management, 35 (4), 505-521.

Salleh, N. M. (2012). An explonatory analysis of the reasons for using non-traditional expatriate assignments. Unpublished Doctoral Dissertation. RMIT University.

Sekaran, U. (2006). Research methods for business: a skill building approach. New Delhi: John Wiley \& Sons, Inc, $4^{\text {th }}$ Ed.

Senge, P., M. (2006). The fifth discipline: the art and practice of the learning organization. UK: Random House -Business Books.

Schuler, R.S., Fulkerson, J.R. and Dowling, P.J. (1991). Strategic performance measurement and management in multinational corporations. Human Resource Management, 30 (3), 365-88. 
Schuler, R. and Florkowski, G. (1994). Auditing human resource management in the global environment. International Journal of Human Resource Management, 5 (4), 827-51.

Stiles, P., Trevor, J., Paauwe, J., Farndale, I., Wright, P., Morris, S., Stahl, G., \& Bjorkman, I. (2006). Best practice and key themes in global human resource management: project report. A researched sponsord by SANYO.

Stone, R.J. (1991). Expatriate selection and failure. Human Resource Planning, 14 (1), 9-18.

Takeda, M., B., \& Helms, M., M. (2010). Globally sustainable management: a dynamic model of IHRM learning and control. The Learning Organization, 17 (2), 133-148.

Trim, P., \& Lee, Y-I. (2007). Placing organizational learning in the context of strategic management. Business Strategy Series, 8 (5), 335-342, 1751-5637.

Viswesvaran, C, \& Ones, D. S. (1999). Meta-analyses of fakability estimates: Implications for personality measurement. Educational and Psychological Measurement, 59 (2), 197-210.

Wang, Y-L. \& Ellinger, A., D. (2011). Organizational learning: Perception of external environment and innovation performance. International Journal of Manpower, 32 (5/6), 512-536.

Watkins, K., \& Marsick, V. (1993). Sculpting the learning organization: Lessons in the art and science of systemic change. San Francisco: Jossey-Bass. 